\title{
PENGARUH KECERDASAN INTELEKTUAL, KEMAMPUAN FISIK DAN KECERDASAN EMOSIONAL TERHADAP KINERJA PEGAWAI SPRIPIM POLDA SULAWESI SELATAN
}

\author{
Muh. Ramli \\ muh.ramli124@gmail.com \\ Program Studi Kewirausahaan \\ Universitas Megabuana Palopo \\ Nurdin \\ nurdin.mjn96@yahoo.co.id \\ Program Studi Kewirausahaan \\ Universitas Megabuana Palopo
}

\begin{abstract}
The research aims to: 1) analyze the influence of intellectual intelligence on the performance of the Spripim Polda of South Sulawesi employees; 2) analyzing the influence of physical ability to the performance of officers Spripim Polda South Sulawesi; 3) Analyzing the influence of emotional intelligence on the performance of Spripim Polda South Sulawesi employees; 4) Analyzing the factors which are dominant influence on the performance of officers Spripim Polda South Sulawesi. The population of this research is all employees of the Spripim Polda South Sulawesi, amounting to 81 people with a whole sample or a saturated sample. The results showed that the influence coefficient of intellectual intelligence on employee performance is 0.330 with the value $p=0.012<0.05$ This suggests that intellectual intelligence has a significant positive effect on employee performance. Influence coefficient of physical ability to employee performance of 0.138 with value $p=0.033<0.05$. This suggests that physical abilities have a significant positive effect on the employee's performance, the influence coefficient of emotional intelligence Ssterhadap employee performance of 0.584 with a value of $P=0.000<0.05$. This suggests that emesional intelligence has a significant positive effect on employee performance, and the highest beta value is an emotional intelligence variable with a beta value of 0.532. This indicates that the dominant influential variable affects the employee's performance as a variable of emotional intelligence.
\end{abstract}

Keywords: Intellectual Intelligence, Physical Ability, Emotional Intelligence, and Performance

\begin{abstract}
Abstrak
Penelitian ini bertujuan untuk : 1) Menganalisis pengaruh Kecerdasan Intelektual terhadap kinerja pegawai Spripim Polda Sulawesi Selatan; 2) Menganalisis pengaruh Kemampuan Fisik terhadap kinerja pegawai Spripim Polda Sulawesi Selatan; 3) Menganalisis pengaruh Kecerdasan Emosional terhadap kinerja pegawai Spripim Polda Sulawesi Selatan; 4)Menganalisis factor mana yang dominan berpengaruh terhadap kinerja pegawai Spripim Polda Sulawesi Selatan. Populasi penelitian ini adalah seluruh pegawai Spripim Polda Sulawesi Selatan yang berjumlah 81 Orang dengan sampel secara keseluruhan atau sampel jenuh. Hasil penletian ini menunjukkan bahwa koefisien pengaruh kecerdasan intelektual terhadap kinerja pegawai sebesar 0,330 dengan nilai $\mathrm{p}=0,012<0,05$. Ini menunjukkan bahwa kecerdasan intelektual berpengaruh positif signifikan terhadap kinerja pegawai. koefisien pengaruh kemampuan fisik terhadap kinerja pegawai sebesar 0,138 dengan nilai $p=0,033<0,05$. Ini menunjukkan bahwa kemampuan fisik berpengaruh positif signifikan terhadap kinerja pegawai, koefisien pengaruh kecerdasan emosional ssterhadap kinerja pegawai sebesar 0,584 dengan nilai $\mathrm{p}=0,000<0,05$. Ini menunjukkan bahwa kecerdasan emesional berpengaruh positif signifikan terhadap kinerja pegawai, dan diperoleh nilai beta yang paling tinggi adalah variable kecerdasan emosional dengan nilai beta sebesar 0,532. Ini menunjukkan bahwa variable yang berpengaruh dominan berpengaruh terhadap kinerja pegawai adalah variable kecerdasan emosional.
\end{abstract}

Kata Kunci : Sistem Antrian, Multiple Channel Query System (M/M/s) 


\section{PENDAHULUAN}

Organisasi modern, peran sentral manusia dalam pencapaian tujuan organisasi tidak terbantahkan. Konsekuensinya adalah, dibutuhkannya anggota organisasi, atau sumber daya manusia, yang tidak saja berkemampuan, tetapi memiliki motivasi tinggi dan beretika. Permasalahan mengenai kinerja merupakan permasalahan yang akan selalu dihadapi oleh pihak manajemen baik di organisasi maupun perusahaan, karena itu manajemen perlu mengetahui faktor-faktor yang mempengaruhi kinerja pegawai.

Faktor-faktor yang dapat mempengaruhi kinerja pegawai tersebut akan membuat perusahaan dapat mengambil berbagai kebijakan yang diperlukan, sehingga dapat meningkatkan kinerja pegawai/ karyawannya agar sesuai dengan visi dan misi organisasi atau harapan perusahaan (Habibah, 2001). Dapat dibayangkan betapa hebatnya jika bisa dibangun suatu sistem manajemen sumber daya manusia yang mampu memotivasi pegawai/karyawannya untuk mengembangkan kemampuan emosinya, sehingga bukan hanya kompetensi teknis yang berkembang tetapi juga produktivitas dan kinerjanya ikut meningkat (Martin, 2000: 25).

Berdasarkan pengamatan penulis tentang kinerja pegawai pada kantor Spripim. Spripim bertugas membantu dalam melaksanakan tugas kedinasan dan tugas khusus dari kapolda dan/atau Wakapolda. Berdasarkan kondisi yang terjadi kantor Spripim Polda Sulawesi Selatan kinerja pegawai terkadang terhambat disebabkan karena interlektual yang berbeda yang dimiliki setiap pegawai dimana dengan kondisi tersebut mengakibatkan kinerja pegawai kurang maksimal disebabkan karena kurangnya pengetahuan terkait dengan dunia perkantoran dan job masing - masing pegawai tersebut. Hal ini menyebabkan banyak pekerjaan yang harus diselesaikan tepat waktu namun tidak terselesaikan dengan baik penyebabnya karena tingkat kecerdasan pegawai belum memadai standar yang sebenarnya.

\section{a. rumusan masalah}

Berdasarkan latar belakang yang telah dipaparkan sebelumnya, maka masalah pokok yang akan dikaji dalam penelitian ini dirumuskan sebagai berikut.

1) Apakah kecerdasan intelektual berpengaruh terhadap kinerja Pegawai Spripim Polda Sulawesi Selatan.

2) Apakah kemampuan fisik berpengaruh terhadap kinerja Pegawai Spripim Polda Sulawesi Selatan.

3) Apakah kecerdasan emosional berpengaruh terhadap kinerja Pegawai Spripim Polda Sulawesi Selatan.

4) Variabel manakah yang dominan berpengaruh terhadap kinerja Pegawai Spripim Polda Sulawesi Selatan.

\section{b. Tujuan Penelitian}

Tujuan yang ingin dicapai dalam penelitian ini adalah.

1) Menganalisis pengaruh kecerdasan intelektual terhadap kinerja Pegawai Spripim Polda Sulawesi Selatan.

2) Menganalisis pengaruh kemampuan fisik terhadap kinerja Pegawai Spripim Polda Sulawesi Selatan.

3) Menganalisis pengaruh kecerdasan emosional terhadap kinerja Pegawai Spripim Polda Sulawesi Selatan.

4) Menganalisis Variabel manakah yang dominan berpengaruh terhadap kinerja Pegawai Spripim Polda Sulawesi Selatan.

\section{c. Manfaat Penelitian}

1. Manfaat Teoritis 
Secara teoritis, Hasil dari penelitian ini diharapkan dapat menjadi referensi atau masukan bagi perkembangan ilmu pengetahuan di Sulawesi selatan serta dapat dijadikan referensi bagi mahasiswa pascasarjana untuk menyelesaikan study.

2. Manfaat Praktis

Dengan adanya penelitian ini diharapkan mampu menambah pengetahuan dan mengembangkan ilmu bagi peneliti.

\section{METODE PENELITIAN}

\section{a. Jenis penelitian}

Jenis Desain peneitian yang digunakan dalam studi ini adalah jenis metodologi peneitian Kuantitatif. Menurut (Singarimbun 1996 ), metode penelitian yang menjelaskan hubungan antara variabel - Variabel melalui pengujian hipotesa.

\section{b. Lokasi Penelitian}

Penelitian ini telah dilakukan di Kantor Spripim Polda Sulawesi Selatan dengan pertimbangan terdapat jumlah Pegawai yang minimal dengan tuntutan pekerjaan yang cukup besar tetapi tidak selalu didukung dengan dukungan internal dan eksternal dari pihak Polda. Pelaksanaan penelitian ini dilakukan selama tiga bulan dari bulan Juni sampai dengan bulan September 2017.

\section{c. Teknik Pengumpulan Data}

Pengumpulan data penelitian dilakukan dengan menggunakan kuesioner yang diisi langsung oleh responden. Skala untuk kuesioner yang akan digunakan adalah skala bentuk langsung karena diisi langsung oleh subyek sendiri dan merupakan skala tertutup karena subyek sudah disediakan jawaban dalam bentuk pilihan. Alat ukur yang berbentuk skala ini merupakan metode yang cukup baik untuk mengambil data. Azwar (2008) mengemukakan bahwa seperangkat pernyataan yang ada dalam skala yang berisikan pernyataan-pernyataan dapat digunakan untuk mengungkap aspekaspek afektif seperti minat, sikap dan berbagai variabel lainnya.

\section{d. Teknik Analisis Data}

Analisis statistik yang menggunakan model analisis Regresi Linear Berganda yang dikemukakan oleh Sugiyono (2008) dengan rumus sebagai berikut :

$\begin{array}{ll}\mathbf{Y}=\mathbf{b 0}+\mathbf{b} 1 \mathbf{x} \mathbf{1}+\mathbf{b} 2 \mathbf{2} \mathbf{2}+\mathbf{b} 3 \mathbf{x} \mathbf{3}+\boldsymbol{\mu} \\ \text { Dimana : } & \\ \mathrm{Y} & =\text { Kinerja Pegawai } \\ \mathrm{X} 1 & =\text { Kecerdasan } \\ & \text { Intelektual } \\ \mathrm{X} 2 & =\text { Kemampuan Fisik } \\ \mathrm{X} 3 & =\text { Kecerdasan } \\ & \text { Emosional } \\ \text { b0 } & =\text { Intercept } \\ \text { b1, b2, b3 } & =\text { Koefesien Regresi } \\ \mu & =\text { Tern Error }\end{array}$

Keseluruhan proses analisis data penelitian ini menggunakan program SPSS-versi 23.0 for windows.

\section{HASIL DAN PEMBAHASAN}

Analisis regresi dilakukan untuk membuktikan hipotesis yang diajukan dalam penelitian ini, yakni untuk menganalisis pengaruh antara variabel bebas terhadap variabel terikat, secara parsial serta untuk menguji hipotesis penelitian yang telah dikemukakan sebelumnya. Dasar pengujian hipotesis dalam penelitian ini menggunakan nilai probabilitas baik untuk uji secara parsial maupun simultan. Secara umum hipotesis yang dikemukakan dalam penelitian ini adalah sebagai berikut:Ho: Tidak terdapat pengaruh antara variabel bebas terhadap 
variabel terikatHa: Terdapat pengaruh antara variabel bebas terhadap variabel terikat.

Dasar pengambilan keputusannya adalah:

$\mathrm{P}<0,05$, maka Ho ditolak

$P \geq 0,05$, maka Ho diterima

Pengujian hipotesis ini dilakukan dengan teknik analisis statistik regresi linear berganda, dari hasil olahan komputer sub program SPSS for windows yang akan dipaparkan melalui tabel-tabel signifikansi. Berikut hasil yang didapatkan sesuai hipotesis yang telah dirumuskan. Hasil Analisis regresi berganda terdapat pada tabel berikut ini:

Tabel 4.12 Hasil Analisis Regresi

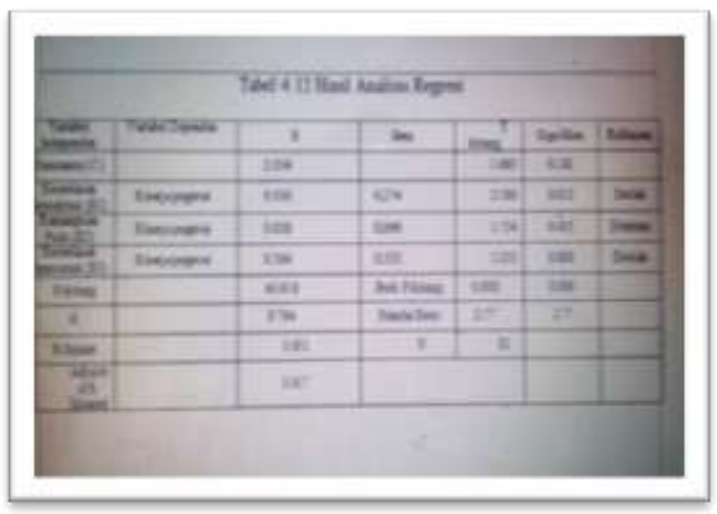

\section{Model Summary}

1. Angka R sebesar 0.794 menunjukkan bahwa korelasi nilai pengamatan dan nilai prediksi cukup kuat.

2. Angka $\mathrm{R}$ square atau koefisien determinasi adalah 0.631. Hal ini berarti bahwa model mempunyai daya ramal $63,1 \%$ variasi $Y$ dijelaskan oleh model.

3. Adjusted $R$ Square yaitu 0.617. Hal ini berarti $61,7 \%$ variasi dari variabel terikat bisa dijelaskan oleh variasi dari variabel bebas, sedangkan sisanya 38,2 dijelaskan oleh variabel lain di luar model.
4. Standard Error of Estimate (SEE) adalah 2,77 Makin kecil SEE akan membuat model regresi semakin tepat memprediksi variabel terikat.

Hasil persamaan regresi yang diperoleh sebagai berikut:

\section{$Y=2.354+0.330 X 1+0.038 X 2+$ $0.584 X 3$}

\section{a. Pengujian Hipotesis}

Berdasarkan rumusan masalah yang diajukan dalam penelitian ini dapat dilakukan pengujian terhadap hipotesis yang diajukan dengan analisis regresi linier berganda. Tabel 4.12 merupakan pengujian hipotesis dengan melihat nilai $\mathrm{p}$ value, jika nilai $\mathrm{p}$ value lebih kecil dari 0.05 maka pengaruh antara variabel signifikan. Hasil pengujian hipótesis sebagai berikut:

Uji hipotesis 1 :Berdasarkan analisis regresi pada tabel 4.12, diperoleh koefisien pengaruh kecerdasan intelektual terhadap kinerja pegawai sebesar 0,330 dengan nilai $\mathrm{p}=0,012<$ 0,05 . Ini menunjukkan bahwa kecerdasan intelektual berpengaruh positif signifikan terhadap kinerja pegawai. Hal ini dapat diartikan bahwa semakin tinggi kecerdasan intelektual seorang pegawai maka kinerja pegawai tersebut semakin tinggi. Sehingga dapat disimpulkan bahwa hipotesis penelitian yang berbunyi "Kecerdasan intelektual (Intellectual Ability) berpengaruh signifikan terhadap kinerja pegawai Spripim Polda Sulawesi Selatan" diterima.

Uji hipotesis 2: Berdasarkan analisis regresi pada tabel 4.12, diperoleh koefisien pengaruh kemampuan fisik terhadap kinerja pegawai sebesar 0,038 dengan nilai $\mathrm{p}=0,453>0,05$. Ini menunjukkan bahwa kemampuan fisikberpengaruh tidak signifikan terhadap kinerja pegawai. Hal ini dapat 
diartikan bahwa kemampuan fisik tidak mempengaruhi kinerja pegawai disebabkan karena anggota polisi diwajibkan untuk menjaga kebugaran tubuh dan setiap bulan harus latihan jasmani dan rohani sehingga kemmapuan fisik sudah terjaga dalam bekerja .ditolak.

Uji hipotesis 3: Berdasarkan analisis regresi pada tabel 4.12, diperoleh koefisien pengaruh kecerdasan emosional terhadap kinerja pegawai sebesar 0,584 dengan nilai $\mathrm{p}=0,000<0,05$. Ini menunjukkan bahwa kecerdasanemosional berpengaruh positif signifikan terhadap kinerja pegawai. Hal ini dapat diartikan bahwa semakin bagus kecerdasanemosional seorang pegawai maka kinerja pegawai tersebut semakin tinggi. Sehingga dapat disimpulkan bahwa hipotesis penelitian yang berbunyi "Kecerdasan emosionalberpengaruh signifikan terhadap peningkatan kinerja pegawai Spripim Polda Sulawesi Selatan" diterima.

Uji hipotesis 4 :Berdasarkan analisis regresi pada tabel 4.12, diperoleh nilai beta yang paling tinggi adalah variable kecerdasan emosional dengan nilai beta sebesar 0,532. Ini menunjukkan bahwa variable yang berpengaruh dominan berpengaruh terhadap kinerja pegawai adalah variable kemampuan emosional. Dengan demikian, maka hipotesis penelitian yang berbunyi "Kecerdasan emosional berpengaruh dominan terhadap kinerja Pegawai Spripim Polda Sulawesi Selatan" diterima.

Pengujian hipotesis dengan menggunakan teknik analisis regresi berganda (multiple regression) dengan bantuan software SPSS version 23. Sebelum sampaipada tahap pengujian hipotesis yang bertujuan untuk melihat pengaruh antar variable independen dengan variabel dependen maka dilakukan terlebih dahulu uji validitas dan reliabilitas serta uji asumsi klasik. Pengujian validitas dan realibilitas bertujuanuntuk melihat valid dan konsistennya indikator penelitian sedangkan uji asumsi klasik bertujuan untuk menguji ada tidaknya hubungan antar variabel independen.

\section{PENUTUP}

\section{a. Kesimpulan}

Hasil analisis dari rumusan masalah, pengujian hipotesis, dan pembahasan,

1. Kecerdasan intelektual berpengaruh positif signifikan terhadap kinerja pegawai sebesar 0,330 dengan nilai $\mathrm{p}=$ $0,012<0,05$. Ini menunjukkan bahwa kecerdasan intelektual berpengaruh positif signifikan terhadap kinerja pegawai. Hal ini dapat diartikan bahwa semakin tinggi kecerdasan intelektual seorang pegawai maka kinerja pegawai tersebut semakin meningkat.

2. Kemampuan fisik berpengaruh positif tidak signifikan terhadap kinerja pegawai sebesar 0,138 dengan nilai $\mathrm{p}=$ $0,453>0,05$. Ini menunjukkan bahwa kemampuan fisik berpengaruh positif tidak signifikan terhadap kinerja pegawai. Hal ini dapat diartikan bahwa kemampuan fisik tidak mempengaruhi kinerja karyawan di sebabkan karena anggota polisi diwajibkan untuk menjaga kebugaran tubuh dan setiap bulan harus latihan jasmani dan rohani sehingga kemampuan fisik sudah terjaga dalam bekerja.

3. Kecerdasan emosional berpengaruh positif signifikan terhadap kinerja pegawai sebesar 0,584 dengan nilai $\mathrm{p}=$ $0,000<0,05$. Ini menunjukkan bahwa kecerdasan emesional berpengaruh positif signifikan terhadap kinerja 
pegawai. Hal ini dapat diartikan bahwa semakin bagus kecerdasan emosional seorang pegawai maka kinerja pegawai tersebut semakin tinggi.

4. Kecerdasan emosional merupakan variable yang paling dominan dengan nilai beta sebesar 0,532. Ini menunjukkan bahwa variabel yang berpengaruh dominan berpengaruh terhadap kinerja pegawai adalah variable kecerdasan emosional.

b. Saran

Hasil dari simpulan penelitian, maka direkomendasikan saran sebagai berikut :

1. Kecerdasan intelektual berpengaruh terhadap kinerja, sehingga disarankan kepada pengambil kebijakan di Polda untuk meningkatkan kecerdasan intelektual sehingga dapat lebih meningkatkan kinerjanya.

2. Kemampuan fisik berpengaruh terhadap kinerja, sehingga disarankan untuk menjaga kemampuan fisik yang dimiliki sehingga dapat menghasilkan kinerja yang baik

3. Kecerdasan emosional berpengaruh terhadap kinerja, sehingga disarankan untuk menjaga dan meningkatkan kecerdasan emosional yang dimiliki untuk lebih meningkatkan kinerja pegawai tersebut.

4. Oleh karena terdapat 38,2 persen faktor yang berpengaruh di luar model, maka disarankan kepada peneliti lain untuk meneliti faktor-faktor lain yang berpengaruh terhadap kinerja pegawai antara lain gaya kepemimpinan, motivasi, kompensasi, kesejahtraan pegawai, dan lain-lain. Menutup kekurangan penelitian. Tidak memuat saran-saran diluar untuk penelitian lanjut.

\section{DAFTAR PUSTAKA}

Agus Nggermanto, 2002, Quantum Quotient (Kecerdasan Quantum) : Cara Tepat Melejitkan IQ, EQ, dan SQ Secara Harmonis, Nuansa, Bandung

Ahmad Purba 1999, Emotional Intelligence, Seri Ayah Bunda, 26 Juli-8 Agustus, Dian Raya, Jakarta

Ary Ginanjar Agustian, 2001, Rahasia Sukses Membangun Kecerdasan Emosi dan Spiritual (ESQ), Arga Wijaya Persada, Jakarta

Ary Ginanjar Agustian, 2001, Rahasia Sukses membangkitkan ESQ Power, Arga Wijaya Persada, Jakarta

Anthony Dio Martin, 2000, Aplikasi EQ Based HR Management System, Majalah Manajemen, No.148, Desember

Behling, 0, 1998, Employee Selection: Will Intelligence and Conscientiousness Do The Job ?, The Academy of Management Executive, 12(1) :7786

Bernardin, J, 1993, The Function of The Executive, Cambridge, Ma. Research of Harvard University

Boyatzis, R,E, Ron, S, 2001, Unleashing the Power of Self Directed Learning, Case Western Reserve University, Cleveland, Ohio, USA

Carruso, D, R, 1999, Applying The Ability Model of Emotional Intelligence ToThe World of Work, http://cjwolfe.com/article.doc, 15 Oktober 2005

Chakraborty, S.K, and Chakraborty, D, 2004, The Transformed Leader and Spiritual Psychology : A Few Insight, Journal of Organizational Change Management, Vol.17, No.2, pp.184210

Chermiss, C, 1998, Working With Emotional Intelligence, The Consortium For Research On Emotional Intelligence in Organizations, Rugrets University, New Jersey 
Cooper Dr, and Emory, C.W, 1995, Metode Penelitian Bisnis, Jilid.1, ed.5, Erlangga, Jakarta

Cooper, R, K, 2002, Executive EQ : Kecerdasan Emosi Dalam Kepemimpinan dan Organisasi, PT. Gramedia Pustaka Utama, Jakarta

Dani Setyawan, 2004, Analisis Pengaruh Kepemimpinan $Q \quad(I Q, E Q, \quad S Q)$ Terhadap Komitmen Organisasional Karyawan, Skripsi, Universitas Katolik Soegijapranata, Semarang

Dessler, G, 1997, Manajemen Sumber Daya Manusia, Alih bahasa :Benyamin Molan, PT. Prenhallindo, Jakarta

Daryono, 2009, Manajemen Sumber Daya Manusia,Indonesia,Gramedia Pustaka Utama.Jakarta

Fendy Suhariadi, 2002, Pengaruh Inteligensi dan Motivasi Terhadap Semangat Penyempurnaan Dalam Membentuk Perilaku Produktif Efisien, Anima : Indonesia Psikologi Jurnal, Vol.17, No.4, Juli 2002, p.346

Goleman, D, 2000, Kecerdasan Emosi : Mengapa Emotional Intelligence Lebih Tinggi Daripada IQ, Alih Bahasa : T. Hermay, PT. Gramedia Pustaka Utama, Jakarta, 2001, Emotional Intelligence Untuk Mencapai Puncak Prestasi, Alih Bahasa : Alex Tri K.W, PT. Gramedia Pustaka Utama, Jakarta

Gordon, E, 2004, EQ dan Kesuksesan Kerja, Focus-online, http://www.epsikologi.com, 12 Desember 2004

Harry Widiantoro, 2001, Menciptakan Eustress Di Tempat Kerja : Usaha Meningkatkan Kinerja Karyawan, Ventura, Vol.4, No.2 September

Mathis, R,L, dan Jackson, 2002, Manajemen Sumber Daya Manusia, Jilid 1 dan 2, Alih bahasa : Bayu Brawira, Salemba Empat, Jakarta
Marwansyah, 2010, Manajemen Sumber Daya Manusia, Edisi Kedua, Alfabeta, Bandung, November.

Moustafa, K,S, and, Miller, T, R, 2003, Too Intelligent For The Job ? The Validity of Upper-Limit Cognitive Ability Test Scores In Selection, Sam Advanced Management Journal, Vol.68

Mutiara S Panggabean, 2002, Pengaruh Keadilan Dalam Penggajian dan Perilaku Individu Terhadap Kinerja Dosen Perguruan Tinggi Swasta, Kajian Bisnis STIE Widya Wiwaha, No.26, Mei-Agustus

Patton, P, 1998, Kecerdasan Emosional di Tempat Kerja, Alih Bahasa : Zaini Dahlan, Pustaka Delaprata, Jakarta

Ravianto, 1988, Production of Management, LSIUP, Jakarta 